\title{
Pola Perilaku Hidup Sehat tidak hanya Berlaku bagi Pasien Melainkan juga Caregiver
}

\author{
Alexandra Arvia ${ }^{(1)}$, Ida Ayu Made Adhi Purnami ${ }^{(2)}$ \\ ${ }^{(1),(2)}$ Fakultas Psikologi, Universitas Surabaya, Jawa Timur, Indonesia
}

\begin{abstract}
In this work, we aimed to examine the effectiveness of a counselling program to improve cancer patient caregivers' health behaviours at Yayasan Kanker Indonesia Jawa Timur (the Indonesian Cancer Foundation, East Java). Caregivers oftentimes experience pressures and demands that make it difficult for them to meet their personal physical and psychological needs. As a consequence, caregivers suffer from stress easily, resulting in their lack of ability to maintain a healthy lifestyle and, ultimately, their proneness to illness. The present research was designed as an experimental study involving 15 caregivers. Substantiating the hypothesis specified, the results showed that the health behaviours of caregivers of cancer patients were significantly improved after they took part in the counselling program.
\end{abstract}

Keywords: cancer patients, caregiver, healthy lifestyles

Tujuan penelitian ini adalah untuk menguji efektivitas penyuluhan untuk meningkatkan perilaku hidup sehat pada para caregiver pasien kanker di Yayasan Kanker Indonesia Jawa Timur. Adanya tekanan dan tuntutan yang dialami oleh caregiver seringkali membuat diri mereka sulit untuk memenuhi kebutuhan fisik dan psikis pribadi. Caregiver menjadi rentan mengalami stres hingga berdampak pada kurangnya kemampuan mereka dalam menjaga pola perilaku hidup sehat, yang menyebabkan mereka mudah mengalami sakit. Penelitian ini didesain sebagai penelitian eksperimen yang melibatkan 15 caregiver. Mendukung hipotesis yang diajukan, hasil eksperimen menunjukkan bahwa penyuluhan dalam penelitian ini efektif dalam meningkatkan pola hidup sehat pada caregiver pasien kanker.

Kata kunci: caregiver, pasien kanker, pola hidup sehat

MEDIAPSI, 2020, Vol. 6(2), 110-118, DOI: https://doi.org/10.21776/ub.mps.2020.006.02.5

Received: 19-03-2020. Revised: 31-07-2020. Accepted: 09-10-2020. Published online: 07-12-2020

Handling Editor: Esti Zaduqisti, IAIN Pekalongan, Jawa Tengah, Indonesia

*Corresponding author Alexandra Arvia, Fakultas Psikologi, Universitas Surabaya, Jawa Timur, Indonesia.

E-mail: aarvia@alumni.ciputra.ac.id

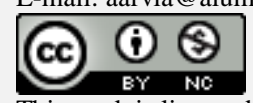

This work is licensed under a Creative Commons Attribution-NonCommercial 4.0 International License.

How to cite this article in accordance with the American Psychological Association (APA) $6^{\text {th }}$ guidelines:

Arvia, A., \& Purnami, I. A. M. A. (2020). Pola perilaku hidup sehat tidak hanya berlaku bagi pasien melainkan juga caregiver. MEDIAPSI, 6(2), 110-118. https://doi.org/10.21776/ub.mps.2020.006.02.5

\section{Pendahuluan}

Caregiver atau pengasuh pasien tidak memandang jenis kelamin. Baik laki-laki maupun perempuan dengan demikian memiliki tanggung jawab yang setara untuk berperan sebagai pengasuh. American Psychological Assosiation (Friedemann \& Buckwalter, 2014) menyatakan bahwa mayoritas pengasuh di seluruh dunia adalah perempuan. Namun demikian, di Amerika Serikat, proporsi pengasuh laki-laki baru-baru ini meningkat menjadi $45 \%$ (Fox \& Brenner, dalam Friedemann \& Buckwalter, 2014), dan tanggung jawab laki-laki semakin bertambah. Berdasarkan hasil wawancara dengan partisipan yang dilakukan oleh peneliti, empat dari lima 
orang merupakan perempuan yang menjadi caregiver di Yayasan Kanker Indonesia Cabang Jawa Timur. Caregiver atau pengasuh merupakan sebuah peran penting dan merupakan sebuah kewajiban personal untuk memenuhi kebutuhan pasien (Cleary, Hunt, Walter, \& Freeman, 2006).

Pengasuh atau keluarga yang merawat pasien disebut juga sebagai family caregiver. Mereka adalah mitra penting yang membantu dalam merawat dan menjaga keluarga mereka (Mitnick, Leffler, Hood, \& American College of Physicians Ethics, Professionalism and Human Rights Committee, 2010; Rahmatiah, Kadar, \& Erika, 2018). Pemberian pelayanan perawatan biasanya diberikan kepada individu lanjut usia, demensia, dan individu yang mengidap penyakit kanker (Bevans \& Stenberg, 2012). Keluarga menjadi pelayan perawatan kesehatan bagi pasien kanker dikarenakan pasien kanker kurang mampu dalam merawat dirinya sendiri terkait dengan pengobatan serta kegiatan sehari-harinya (Rahmatiah, Kadar, \& Erika, 2018). Kebanyakan dari mereka mengambil tanggung jawab lebih secara tibatiba tanpa adanya pelatihan dan dengan sumber daya yang terbatas. Hal tersebut dikarenakan penyakit kanker yang divoniskan pada pasien kanker merupakan penyakit yang tidak terduga (Van Ryn dkk., 2011).

Seseorang yang dinyatakan terkena kanker umumya mengalami ketakutan, kecemasan, dan stress, yang mengaktifkan hormon katekolamin atau hormon pengurang nafsu makan (Billes \& Cowley, 2008). Sebagai dampak dari penyakit dan pengobatan yang mereka jalani, pasien kanker memiliki berbagai keluhan fisik dan mental (Weaver dkk., 2012). Variasi keluhan tersebut membuat pasien kanker menjadi sangat tergantung kepada orang lain, dalam hal ini adalah caregiver (Lund, Ross, Petersen, \& Groenvold, 2014). Adapun beberapa keluhan yang dialami oleh pasien kanker di Yayasan Kanker Indonesia Cabang Jatim yang diperoleh berdasarkan hasil wawancara peneliti diuraikan sebagai berikut:
"Ya ini mbak, suami saya kalo habis sinar radiasi pasti susah makannya, terus biasa ya mual dan muntah. Jadi ya saya ngga tau harus ngapain wong dianya gabisa makan. Saya cuma bisa ngeliatin kasian. Jadi ngga tega buat makan didepan suami”- Istri pasien kanker Nasofaring.

"Iya ngono mari kemo kan emang biasanya istri saya suka ngerasa mual sama bagian ininya (menunjuk bagian ketiak), itu kayak ketusuk-tusuk jarum, nah kalo uda mual itu ndak bisa ditahan tapi langsung keluar gitu, nah itu ngaruh ke nafsu makannya"- Suami pasien Kanker Payudara.

Berdasarkan hasil wawancara di atas, dapat dilihat bahwa setelah pasien mengikuti kemoterapi ataupun radiasi, mereka mengalami rasa mual hingga menimbulkan kelemahan fisik. Pasien kanker juga mengalami penurunan nafsu makan karena dampak dari kemoterapi dan radiasi. Penyakit kanker dengan demikian sangat mempengaruhi bagaimana kondisi kesehatan mental maupun fisik pasien, yang menyebabkan pasien mengalami ketergantungan dengan caregiver. Sebanyak 86.6\% pasien kanker memiliki ketergantungan pada caregiver dengan tingkatan yang bervariasi, dan jumlah yang terbesar, yaitu $36.7 \%$, mengalami ketergantungan dalam kategori berat (Werdani, 2018). Caregiving secara menyeluruh dengan demikian sangat perlu dilakukan, menimbang minimnya tingkat kemandirian pasien tersebut.

Tuntutan memberikan caregiving yang total membuat caregiver memiliki tanggung jawab lebih untuk memerhatikan dan memenuhi semua kebutuhan pasien seperti memberikan dukungan langsung kepada pasien, memberikan obat-obatan, menyediakan transportasi, menyiapkan makanan, mengelola keuangan, mengurus administrasi rumah sakit, dan memberikan dukungan secara emosional. Perhatian dan tanggung jawab tersebut membuat caregiver menjadi kurang mendapatkan dukungan keluarga untuk diri 
mereka sendiri (Bevans \& Sternberg, 2012). Sebagai dampak ikutannya, penyakit kanker tidak hanya mempengaruhi gaya hidup pasien kanker melainkan juga pada pendamping pasien atau caregiver. Masalah ini bersumber pada kenyataan bahwa ketika mendapatkan diagnosa kanker, pasien dan keluarga mengalami stress yang signifikan (Edwards \& Clarke, 2004).

Caregiver melaporkan berbagai masalah dari pengalaman pendampingan mereka. Masalah ini mencakup konflik peran sosial, keterbatasan kegiatan yang dilakukan, konflik dalam hubungan perkawinan dan keluarga, tekanan psikologis, dan kesehatan fisik yang menurun. Caregiver menjadi lalai dengan kesehatan mereka sendiri karena berfokus pada kesehatan pasien kanker. Hal ini sesuai dengan pernyataan Bevans dan Sternberg (2012) bahwa permasalahan yang dialami oleh caregiver berupa kelelahan, gangguan tidur, dan perilaku tidak sehat. Kelelahan dan gangguan tidur serta perilaku tidak sehat membuat caregiver menjadi tertekan dan merasa kelelahan sehingga terkadang menjadi orang yang sensitif. Rangkaian tugas dan peran inilah yang menyebabkan tingginya tekanan yang dirasakan oleh caregiver, yang menurunkan kualitas perawatan yang dilakukan. Tekanan yang dialami oleh caregiver terkadang berdampak pada perlakuan caregiver terhadap pasien yang menyebabkan menurunnya kesehatan pasien, sebagaimana bisa dicermati pada kutipan hasil wawancara sebagai berikut:

"Biasanya yang saya rasain sih capek mbak, kan harus mijitin suami sampe dia tidur, kalo dia belum tidur jadi saya ya ngga tidur. Terkadang karena capek saya biarin aja, tapi kalo ngga dipijit dia ngga bisa tidur mbak dan merasa kalo aku ngga mau ngurusin dia, ya rada jengkel sih.. itu yang bikin saya lebih ke diem daripada marah, di diemin aja dia sering merasa kepikiran dan gamau tidur seolah saya ngga mau ngurusin dia, padahal besoknya harus ke rumah sakit untuk kontrol dan lakuin sinar" - Istri pasien Kanker Nasofaring.
"Perasaannya ya gimana ya mbak, kalo capek ya gaboleh kan ibuk lagi sakit, cuma sering sih ngerasa gregetan sama kamauannya yang kayak anak kecil. Sampe aku lupa makan 2 hari pernah, makanku ya gak teratur disini. Sempet masuk rs gara-gara lupa makan saking kepikirannya sama ibu. Ini malah pasien kankernya yang ngerawat aku haha... sampai-sampai kondisi ibuk saat itu drop dan Hbnya ngga mau naik. Pernah mbak aku marahin ibu karena ibu cerewet dan ngga mau tidur, itu kondisi sayang kelelahan karena kurang tidur padahal esok paginya harus ke rs buat ambil antrean pagi-pagi" - Anak pasien Kanker Serviks.

"Saya ya sering nangis mbak karena kepikiran sama kuliah saya di kalimantan gimana, sedangkan bapak disini sakit. Kasian sama bapak buat kepikiran juga kadang bapak sampe gamau tidur karena ngalihin pikirannya ke hp. Ya saya capek sih disini gak ada kegiatan, kerjanya makan dan tidur, ngga ada aktivitas lain lagi, disini paling sering makan mie instan beli di warung" - Anak pasien kanker Kelenjar Getah Bening.

Hasil wawancara yang dilakukan peneliti dengan caregiver di Yayasan Kanker Indonesia memperlihatkan bahwa kondisi caregiver sangat mempengaruhi bagaimana kondisi kesehatan pasien. Dengan demikian, hal yang sangat penting bagi caregiver untuk menjaga pola hidup seperti pola makan, tidur, dan aktivitas yang dilakukan ketika mendampingi pasien kanker di Yayasan Kanker Indonesia. Hal tersebut berdampak pada kesehatan caregiver. Dari hasil wawancara terlihat bahwa semenjak menjadi caregiver yang bertanggung jawab dalam menjaga dan merawat pasien terjadi pola hidup yang tidak sehat seperti makan tidak teratur, tidak cukup tidur, dan tidak melakukan aktivitas apapun untuk meregangkan otot-otot.

Selain itu, caregiver juga berperan memberikan berbagai bantuan, seperti pemberian obat, dukungan emosional, bantuan 
perawatan diri, dan dukungan keuangan. Peran caregiver tersebut membuat pengasuh atau keluarga mengalami cukup banyak kesulitan seperti permasalahan fisik, sosial, dan masalah ekonomi (Rahmatiah dkk., 2018). Akibatnya, caregiver memiliki banyak masalah kesehatan, seperti gangguan tidur dan kelelahan sehingga memperburuk fungsi fisik pasien dan peningkatan beban bagi caregiver. Jika dibandingkan dengan non-caregivers, caregiver sering mengalami masalah psikologis, perilaku, dan fisiologis yang dapat menyebabkan gangguan fungsi sistem kekebalan tubuh dan resiko penyakit jantung koroner hingga menyebabkan kematian dini (Bevans \& Sternberg, 2012; Pinquart \& Sörensen, 2003). Caregiver merupakan perawat bagi pasien kanker, namun tidak dapat dipungkiri bahwa kesehatan caregiver juga sangat penting.

Pola hidup sehat sangat kurang di kalangan caregiver di Yayasan Kanker Indonesia Cabang Jawa Timur. Pola hidup sehat merupakan kebiasaan hidup yang berpegang pada prinsip menjaga kesehatan. Guang (dalam Sulistiarini \& Hargono, 2018) menyatakan bahwa $80 \%$ penyakit kronis yang menyerang manusia disebabkan oleh gaya hidup yang salah, dan 20\% sisanya disebabkan faktor lain. Menjalani perilaku sehat dengan demikian merupakan keharusan bagi tiap orang jika ingin hidupnya sehat dan bermanfaat bagi orang lain. Kesehatan tidak sebatas dimaknai secara fisik, seperti otot maupun bentuk tubuh yang kuat dan kekar. Kesehatan juga dimaknai secara rohani, yang membuat individu tidak mudah menderita gangguan jiwa (Suharjana, 2012). Irianto (2000) mengemukakan bahwa untuk mencapai kebugaran dan kesehatan, seseorang harus mengatur makanan, beristirahat secara cukup, dan berolahraga teratur. Dengan demikian, pola hidup sehat akan mencakup pola makan, menjaga kesehatan pribadi, istirahat yang cukup, dan aktif berolahraga.

Orang yang berperilaku hidup sehat memiliki sejumlah ciri. Mereka mengonsumsi makanan dengan gizi seimbang, mengonsumsi makanan berserat tinggi seperti sayuran dan buah segar setiap hari, menghindari makanan yang mengandung banyak lemak, gula, atau garam. Mereka juga mengonsumsi susu atau produk dari susu setiap hari, tenang dan selalu berpikir positif, serta berupaya menjaga berat badan dalam batas normal. Orang yang berperilaku hidup sehat juga berolahraga teratur, cukup istirahat, minum air putih 1.5-2 liter per hari, dan tidak merokok (Suharjana, 2012). Ketika mengetahui bagaimana pola hidup sehat penting bagi kesehatan dirinya, seorang caregiver diharapkan mampu menjalani pola hidup sehat di Yayasan Kanker Indonesia. Pada akhirnya, caregiver tidak mudah merasa kelelahan, tertekan, karena sudah memiliki fisik dan psikis yang sehat untuk menjadi pendamping dan perawat pasien.

Tujuan dari penelitian ini adalah untuk mengetahui efektivitas program penyuluhan dalam memperbaiki perilaku hidup sehat pada para caregiver pasien kanker di Yayasan Kanker Indonesia Jawa Timur. Atas dasar tujuan ini, hipotesis yang diajukan adalah bahwa program penyuluhan efektif dalam memperbaiki perilaku hidup sehat caregiver.

\section{Metode}

\section{Partisipan dan desain penelitian}

Subjek penelitian adalah caregiver pasien kanker di Yayasan Kanker Indonesia Jawa Timur yang berjumlah 15 orang. Caregiver berasal dari berbagai daerah seperti Tarakan, Lumajang, Tuban, Jombang, Jember, Palembang, Sampang, Lamongan, NTT, Kendari, dan Pamekasan. Caregiver memiliki kisaran usia dewasa yakni 20 hingga 50 tahun. Mayoritas caregiver berstatus ekonomi menengah ke bawah.

Penelitian ini didesain sebagai eksperimen pre-test dan post-test. Dalam eksperimen ini, kecenderungan perilaku hidup sehat caregiver diukur sebelum (pre-test) dan setelah mengikuti penyuluhan (post-test). 


\section{Prosedur dan pengukuran}

Kegiatan penyuluhan dilakukan dalam waktu 3.5 jam, yang terdiri dari empat sesi. Sesi pertama membahas peran dan pentingnya caregiver, sementara sesi kedua membahas pola hidup sehat dan perilaku yang dapat diaplikasikan dalam kehidupan sehari-hari. Sesi ketiga membahas dampak kesehatan bagi caregiver dan pengaruhnya terhadap perlakuan caregiver kepada pasien. Sesi keempat sekaligus terakhir mendiskusikan cara menghadapi pasien tanpa melalaikan kesehatan pribadi. Penyuluhan juga dilengkapi dengan kehadiran narasumber yakni seorang dokter muda untuk memaksimalkan pemberian ilmu pengetahuan terkait penyakit degeneratif seperti sakit jantung, kanker, dan diabetes. Metode kegiatan dalam penyuluhan ini meliputi, pertama, kegiatan partisipatif - eksperensial, yaitu pembelajaran dengan melibatkan semua caregiver dalam diskusi dan juga permainanpermainan yang dilakukan. Kedua adalah kegiatan informatif - lecturing, yaitu ceramah yang bertujuan untuk meningkatkan pemahaman caregiver tentang materi yang disampaikan oleh tim penyuluh secara terperinci. Ketiga adalah kegiatan menggunakan audio - visual sebagai metode yang diberikan agar caregiver dapat melihat secara nyata keadaan di lapangan. Pembelajaran dilakukan dengan menampilkan tayangan video yang menceritakan situasi dari materi yang ingin disampaikan. Keempat adalah games yang bertujuan untuk membantu caregiver dalam mengaplikasikan materi serta membuat suasana penyuluhan menjadi rileks dan menyenangkan. Kelima adalah roleplay yang diberikan dengan tujuan agar caregiver mampu menghadapi keadaan yang sebenarnya di lapangan. Roleplay yang diberikan berupa bermain peran ketika caregiver akan melakukan gerakan-gerakan olahraga yang bisa dilakukan dalam ruangan kecil.

Perilaku hidup sehat dalam penelitian ini diukur menggunakan skala Health Promoting Lifestyle Profile II (HPLP II) dari
Walker dan Hill-Polerecky (dalam Sousa, Gaspar, Vaz, Gonzaga, \& Dixe, 2015), dengan nilai Cronbach alpha $(\alpha)$ sebesar .94. HPLP II memiliki item sebanyak 52 butir, yang terbagi ke dalam 6 subskala. Subskala pertama adalah health responsibility atau responsibilitas terhadap kesehatan (9 aitem), kedua adalah physical activity atau aktivitas fisik (8 aitem), ketiga adalah nutrition atau nutrisi (9 aitem). Sementara itu, subskala keempat adalah spiritual growth atau pertumbuhan spiritual (9 aitem), kelima adalah interpersonal relations atau relasi interpersonal (9 aitem), dan keenam adalah stress management atau manajemen stres ( 8 aitem). Pengisian pada skala ini menggunakan skala Likert dengan rentang 1 (tidak pernah) sampai dengan 4 (rutin).

\section{Hasil}

Sebelum melakukan uji hipotesis, peneliti terlebih dahulu menguji asumsi normalitas menggunakan Kolmogorov Smirnov. Hasil menunjukkan bahwa skor Healthy Promoting Lifestlye Profile II (HPLP II) tidak terdistribusi secara normal. Mengacu pada hasil ini, peneliti menggunakan statistik non parametrik Wilcoxon signed rank (Woolson, 2007) untuk menguji hipotesis penelitian.

Tabel 1. Nilai Aspek-Aspek Health Promoting Lifestyle II (HPLP II) Profile Pre-Test dan Post-Test

\begin{tabular}{|c|c|c|}
\hline Aspek & $p$ & Keputusan \\
\hline $\begin{array}{l}\text { Human } \\
\text { responsibility }\end{array}$ & .005 & $\begin{array}{l}\text { Perbedaan } \\
\text { signifikan }\end{array}$ \\
\hline Physical activity & .072 & $\begin{array}{l}\text { Perbedaan tidak } \\
\text { signifikan }\end{array}$ \\
\hline Nutrition & .343 & $\begin{array}{l}\text { Perbedaan tidak } \\
\text { signifikan }\end{array}$ \\
\hline Spiritual growth & .999 & $\begin{array}{l}\text { Perbedaan tidak } \\
\text { signifikan }\end{array}$ \\
\hline $\begin{array}{l}\text { Interpersonal } \\
\text { relations }\end{array}$ & .269 & $\begin{array}{l}\text { Perbedaan tidak } \\
\text { signifikan }\end{array}$ \\
\hline Stress management & .509 & $\begin{array}{l}\text { Perbedaan tidak } \\
\text { signifikan }\end{array}$ \\
\hline
\end{tabular}

Keterangan: $p=$ signifkansi nilai pre test - post test 
Analisis Wilcoxon signed rank menunjukkan bahwa secara keseluruhan, penyuluhan terbukti efektif meningkatkan perilaku hidup sehat caregiver dalam penelitian ini. Dengan hasil ini, hipotesis dalam penelitian ini diterima.

Sementara itu, efektivitas penyuluhan dalam meningkatkan masing-masing aspek perilaku sehat caregiver ditampilkan dalam Tabel 1 di atas.

Sebagaimana bisa dilihat pada Tabel 1, di antara lima aspek perilaku sehat caregiver, hanya aspek human responsibility yang terbukti berbeda secara signifikan antara pre-test dan post-test. Temuan ini mengandung arti bahwa aspek human responsibility berkontribusi paling besar dalam perilaku sehat caregiver, dibandingkan dengan aspek-aspek lainnya (physical activity, nutrition, spiritual growth, interpersonal relations, dan stress management).

\section{Diskusi}

Sesuai dengan pengertian kesehatan menurut WHO (Adliyani, 2015), individu yang sehat tidak hanya terbebas dari penyakit melainkan juga terbebas dari pikiran dan emosiemosi negatif. Pada penyuluhan ini caregiver dituntut untuk bersedia membagikan pengalaman dan keluhan mereka sebagai pendamping pasien kanker. Hal ini bertujuan untuk meringankan beban psikis caregiver dan memperoleh dukungan sosial dari sesama caregiver pasien kanker.

Berdasarkan data hasil observasi sesi pertama, para caregiver bersedia dan berani untuk membagikan pengalaman dan keluh kesah pribadinya dalam menjalani hidup sebagai pendamping pasien. Adanya faktor eksternal seperti tuntutan ekonomi untuk membayar biaya perawatan dan keterpaksaan untuk meninggalkan kewajiban dan pekerjaannya memberikan tekanan tersendiri dalam diri mereka atau yang disebut dengan caregiver burden (Adelman, Tmanova, Delgado, Dion, \& Lachs, 2014; Bastawrous,
2013; Schulze \& Rössler, 2005). Di sisi lain, caregiver juga kurang memiliki pengetahuan dan informasi mengenai pentingnya peran pendamping dan dampak dari perilaku tidak sehat mereka terhadap pasien yang mereka rawat (Angelo, Egan, \& Reid, 2013). Hal ini dijelaskan secara langsung melalui materi yang diberikan oleh pemateri dan narasumber. Berdasarkan hasil observasi, para pendamping pasien mampu memperhatikan, menyimak dan berdiskusi dengan baik selama penyuluhan. Hal ini memperkuat adanya peningkatan pengetahuan mengenai pola hidup sehat caregiver.

Hasil analisis data menujukkan adanya pengingkatan skor skala HPLP (Health Promoting Lifestyle Profile) setelah caregiver mengikuti penyuluhan. Hal ini mengindikasikan bahwa pemberian penyuluhan yang dilakukan mampu memberikan kesadaran bagi para pendamping pasien kanker (caregiver) untuk lebih bertanggung jawab terhadap kesehatan pribadi mereka. Kesadaran ini berujud inisiatif untuk mencari informasi seputar kesehatan pribadi bersama tenaga professional. Selain itu, caregiver juga bersedia untuk terlibat dalam memeriksa kondisi fisik masing masing serta aktif dan kritis menanyakan permasalahan kesehatan yang dialami kepada pemateri dan narasumber.

Tidak sedikit dari para caregiver yang merasa bahwa dirinya tidak yakin untuk memiliki pola hidup sehat. Hal ini dikarenakan minimnya sarana pengetahuan dan faktor ekonomi yang dimiliki. Adanya penyuluhan ini mampu membantu para caregiver pasien kanker memiliki pengetahuan tentang kesehatan dan dampak dari pola perilaku tidak sehat. Bahkan, para caregiver pasien kanker juga diberikan pandangan baru bahwa hidup sehat tidak harus memerlukan biaya mahal. Hal ini bertujuan untuk meningkatkan motivasi dan keyakinan caregiver untuk hidup sehat. Sementara itu, aspek HPLP lainnya seperti physical activity, nutrition, spiritual growth, interpersonal relation, dan stress management tidak 
mengalami peningkatan. Hal ini dikarenakan materi penyuluhan tidak berfokus pada kelima aspek tersebut.

Efektivitas penyuluhan yang dilakukan juga didukung berdasarkan hasil follow up terhadap perubahan perilaku caregiver pasien kanker. Hasil yang diperoleh melalui proses wawancara menunjukkan bahwa caregiver yang mengikuti penyuluhan sudah mampu untuk memulai pola hidup sehat dengan langkah awal sederhana seperti mulai memperbanyak mengkonsumsi air mineral, makan teratur, dan melakukan aktivitas fisik seperti berjalan kaki. Adanya dampak positif dari kebiasaan pola hidup sehat yang baru seperti tubuh yang menjadi lebih fit membuat caregiver bersedia untuk berbagi sukacita dengan sesama caregiver lainnya di RS. Soetomo. Selain bercerita, caregiver juga menyebarkan brosur terkait pola hidup sehat ke pendamping pasien kanker yang mereka tidak sengaja temui saat bersama-sama saling menunggu pengobatan pasien di rumah sakit.

Tidak hanya itu, Yayasan Kanker Indonesia Cabang Timur juga ikut berperan dalam mengambil bagian untuk membantu menyadarkan masyarakat terkait pentingnya pola hidup sehat bagi caregiver. Yayasan juga ikut menyediakan brosur pola hidup sehat yang bertujuan untuk memberikan pemahaman pentingnya pola hidup sehat bagi dirinya, jika ada caregiver pasien kanker berkunjung. Hal ini membuahkan hasil yang diharapkan. Sebagai contoh, hasil wawancara bersama Kak Putri, Kak Lina dan Kak Rosa menunjukkan bahwa caregiver mengetahui betapa pentingnya untuk menjaga kesehatan karena sehat itu mahal. Hal ini yang memotivasi mereka untuk mulai menerapkan perilaku sehat.

Sebagai kesimpulan, mengacu pada hasil uji statistik yang sudah dilakukan, pemberian penyuluhan sebagai psikoedukasi berkaitan dengan perilaku pola hidup sehat kepada caregiver cukup efektif. Hal tersebut dibuktikan dengan meningkatnya pengetahuan caregiver antara sebelum dan sesudah pelatihan. Hal ini juga membuktikan bahwa psikoedukasi cukup berperan dalam mengubah pemahaman dan pengetahuan seseorang berkaitan dengan perilaku pola hidup sehat caregiver yang dapat berdampak secara langsung pada kesehatan pasien kanker.

Berdasarkan hasil-hasil temuan dalam penelitian ini, peneliti mengajukan saran kepada sejumlah pihak. Pertama, bagi para caregiver pasien kanker, diharapkan bahwa mereka lebih berkomitmen dan konsisten dalam menerapkan perilaku sehat sebagai upaya untuk merubah pola hidup sehat agar tidak terkena penyakit. Caregiver juga diharapkan bersedia membagikan informasi yang diberikan selama penyuluhan kepada masyarakat luas mengenai pentingnya kesehatan bagi kehidupan individu.

Pihak kedua adalah Yayasan Kanker Indonesia, yang diharapkan untuk selalu memberikan pengetahuan mengenai pola hidup yang sehat dan memberitahukan kepada caregiver untuk tetap menjaga kesehatan. Langkah ini penting karena kesehatan caregiver juga merupakan hal penting.

Penelitian ini mengandung sejumlah kekurangan, yang bisa dibenahi dalam studistudi lanjutan. Kelemahan pertama terkait dengan tidak adanya variabel-variabel lain yang dikendalikan, yang juga berpotensi mempengaruhi perilaku sehat caregiver. Variabel-variabel tersebut bisa berupa faktor pekerjaan, sosial, finansial, fisik, dan waktu dari caregiver (Mochari-Greenberger \& Mosca 2012), yang bisa dikendalikan pengaruhnya dalam studi lanjutan. Kelemahan kedua terkait dengan terbatasnya sampel dalam penelitian ini, yang difokuskan pada caregiver pada penderita kanker. Implikasinya, temuan dalam penelitian ini perlu diuji generalisasinya ke sampel yang berbeda, yang bisa dilakukan pada studi lanjutan. Mengacu pada penelitian-penelitian sebelumnya, sampel alternatif tersebut misalnya adalah pasien atau penderita Alzeimer (Mohamed, Rosenheck, Lyketsos, \& Schneider, 2010) dan penyakit-penyakit kronis lainya (Hagedoorn dkk., 2017). 


\section{Daftar Pustaka}

Adelman, R. D., Tmanova, L. L., Delgado, D., Dion, S., \& Lachs, M. S. (2014). Caregiver burden: A clinical review. Jama, 311(10), 1052-1060. https://doi.org/10.1001/jama.2014.304

Adliyani, Z. O. N. (2015). Pengaruh perilaku individu terhadap hidup sehat. Majority, 4(7), 109-114. Diakses dari https://juke.kedokteran.unila.ac.id/index.p $\mathrm{hp} /$ majority/article/view/1458/1293

Angelo, J. K., Egan, R., \& Reid, K. (2013). Essential knowledge for family caregivers: A qualitative study. International journal of palliative nursing, 19(8), 383-388. https://doi.org/10.12968/ijpn.2013.19.8.3 83

Bastawrous, M. (2013). Caregiver burden-A critical discussion. International journal of nursing studies, 50(3), 431-441. https://doi.org/10.1016/j.ijnurstu.2012.10. 005

Bevans, M., \& Stenberg, E. M. (2012). Caregiving burden, stress, and health effects among family caregivers of adult cancer patients. Journal of American Medical Association, 307(4). https://doi.org/10.1001/jama.2012.29

Billes, S. K., \& Cowley, M. A. (2008). Catecholamine reuptake inhibition causes weight loss by increasing locomotor activity and hermogenesis. Neuropsychopharmacolog $y, 33(6)$, 1287-1297. https://doi.org/10.1038/sj.npp.1301526

Cleary, M., Hunt, G. E., Walter, G., \& Freeman, A. (2006). The patient's view of need and caregiving consequences: A cross-sectional study of inpatients with severe mental illness. Journal of Psychiatric and Mental Health Nursing, 13(5), 506-514. https://doi.org/10.1111/j.13652850.2006.00972.x
Edwards, B., \& Clarke, V. (2004). The psychological impact of a cancer diagnosis on families: The influence of family functioning and patients' illness characteristics on depression and anxiety. Psycho-Oncology: Journal of the Psychological, Social and Behavioral Dimensions of Cancer, 13(8), 562-576. https://doi.org/10.1002/pon.773

Friedemann, M. L \& Buckwalter, K. C. (2014). Family caregiver role and burden related to gender and family relationships. Journal of Family Nursing, 20(3), 313$336 . \quad$ https://doi.org/ 10.1177/1074840714532715

Hagedoorn, E. I., Paans, W., Jaarsma, T., Keers, J. C., van der Schans, C., \& Luttik, M. L. (2017). Aspects of family caregiving as addressed in planned discussions between nurses, patients with chronic diseases and family caregivers: A qualitative content analysis. $B M C$ Nursing, 16(1), $1-10$. https://doi.org/10.1186/s12912-017-02315

Irianto, D. P. (2000). Panduan olahraga untuk kesehatan dan kebugaran. Yogyakarta: Penerbit Andi.

Lund, L., Ross, L., Petersen, M. A., \& Groenvold, M. (2014). Cancer caregiving tasks and consequences and their associations with caregiver status and the caregiver's relationship to the patient: A survey. BMC Cancer, 14(1), 541. https://doi.org/10.1186/1471-2407-14-541 Mitnick, S., Leffler, C., Hood, V. L., \& American College of Physicians Ethics, Professionalism and Human Rights Committee. (2010). Family caregivers, patients and physicians: Ethical guidance to optimize relationships. Journal of General Internal Medicine, 25(3), 255260. https://doi.org/10.1007/s11606-0091206-3

Mochari-Greenberger, H., \& Mosca, L. (2012). Caregiver burden and nonachievement of 
healthy lifestyle behaviors among family caregivers of cardiovascular disease patients. American Journal of Health Promotion, 27(2), 84-89. https://doi.org/10.4278\%2Fajhp.110606QUAN-241

Mohamed, S., Rosenheck, R., Lyketsos, C. G., \& Schneider, L. S. (2010). Caregiver burden in Alzheimer disease: Crosssectional and longitudinal patient correlates. The American Journal of Geriatric Psychiatry, 18(10), 917-927. https://doi.org/10.1097/JGP.0b013e3181d $5745 d$

Pinquart, M., \& Sörensen, S. (2003). Differences between caregivers and noncaregivers in psychological health and physical health: A metaanalysis. Psychology and Aging, 18(2), $250 . \quad$ https://doi.org/10.1037/08827974.18.2.250

Rahmatiah, Kadar, K., \& Erika, K.A. (2018).

Tingkat keterlibatan dan kualitas hidup family caregivers dalam merawat pasien kanker di RSUD Wahidin Sudirohusodo Makasar. Nurscope. Jurnal Keperawatan Pemikiran Ilmiah 4(5), 94-99. Diakses dari https://docplayer.info/132059962Tingkat-keterlibatan-dan-kualitas-hidupfamily-caregivers-dalam-merawat-pasienkanker-di-rsud-wahidin-sudirohusodomakasar.html

Schulze, B., \& Rössler, W. (2005). Caregiver burden in mental illness: Review of measurement, findings and interventions in 2004-2005. Current Opinion in Psychiatry, 18(6), 684-691. https://doi.org/10.1097/01.yco.000017950 4.87613 .00

Sousa, P., Gaspar, P., Vaz, D. C., Gonzaga, S., \& Dixe, M. A. (2015). Measuring health-promoting behaviors: Cross-cultural validation of the health-promoting lifestyle profile-II. International Journal of
Nursing Knowledge, 26(2), 54-61. https://doi.org/10.1111/2047-3095.12065 Suharjana. (2012). Kebiasaan berperilaku hidup sehat dan nilai-nilai pendidikan karakter. Jurnal Pendidikan Karakter, 2, 189-201. https://doi.org/10.21831/jpk.v0i2.1303

Sulistiarini \& Hargono, R. (2018). hubungan perilaku hidup sehat dengan status kesehatan masyarakat Kelurahan Ujung. Jurnal Promkes, 6(1), 12-22. https://doi.org/10.20473/jpk.V6.I1.2018.1 2-22

Van Ryn, M., Sanders, S., Kahn, K., Van Houtven, C., Griffin, J. M., Martin, M., ... \& Rowland, J. (2011). Objective burden, resources, and other stressors among informal cancer caregivers: A hidden quality issue?. Psycho-oncology, 20(1), 44-52. https://doi.org/10.1002/pon.1703

Weaver, K. E., Forsythe, L. P., Reeve, B. B., Alfano, C. M., Rodriguez, J. L., Sabatino, S. A., ... \& Rowland, J. H. (2012). Mental and physical health-related quality of life among US cancer survivors: Population estimates from the 2010 National Health Interview Survey. Cancer Epidemiology and Prevention Biomarkers,21(11), 2108-2117. https://doi.org/10.1158/10559965.EPI-12-0740

Werdani, Y. D. W. (2018). pengaruh caregiving pada pasien kanker terhadap tingkat caregiver burden. Jurnal Ners dan Kebidanan, 5(3), 249-256. Diakses dari http://repository.wima.ac.id/18152/

Woolson, R. F. (2007). Wilcoxon signed-rank test. Wiley Encyclopedia of Clinical Trials, 1-3. https://doi.org/10.1002/9780471462422.e oct979 